\title{
Para ser rico y feliz: un nuevo contexto de estudio de la obra de Thomas Traherne
}

\author{
Ana Elena GoNZÁLEZ TREviño \\ Universidad Nacional Autónoma de México
}

La increíble historia de Thomas Traherne (ca. 1637-1675) es la historia del tesoro escondido que se encuentra. En 1898 un hombre compró dos viejos manuscritos anónimos en un puesto callejero. Un especialista en el siglo XVII, Alexander Grosart, los atribuyó al poeta Henry Vaughan, cuyos textos estaba editando en esa época. En 1903 otro editor, Bertram B. Dobell, al notar que se trataba de una sensibilidad totalmente distinta de la de Vaughan, descubrió el nombre de Thomas Traherne luego de una emocionante búsqueda detectivesca. (Dobell, lxxxvii-xcvi) Más adelante se le atribuyeron cuatro libros anónimos impresos en la transición del siglo XVII al XVIII. En 1910, otro estudioso encontró un manuscrito más que había pasado inadvertido en la Biblioteca Británica y que llevaba el nombre de Traherne. (Bell, xviii-ix) Dos manuscritos más aparecieron después nada menos que en la biblioteca del mismo Grosart. Las ediciones empezaron a aparecer en cuanto se hicieron los primeros hallazgos, $y$ culminaron en 1958, con la edición Oxford en dos volúmenes, a cargo de H. M. Margoliouth.

En 1964, un coleccionista de libros de la Universidad de Yale, James Osborn, compró un manuscrito anónimo sin verlo siquiera, porque se sospechaba que era de Traherne. Más adelante se comprobó que en efecto lo era (Osborn, 1964: 43-47; Osborn, 1974: 160-162). El suceso más sorprendente, sin embargo, tuvo lugar en 1967, en Lancashire, cuando un hombre llegó a un tiradero de basura en busca de refacciones para su auto, y rescató de las llamas un voluminoso libro manuscrito que no fue identificado sino hasta 1982 en la Universidad de Toronto. Resultó ser una obra monumental de Traherne, una especie de enciclopedia de la felicidad, que compró después la Biblioteca Británica por una fortuna. (Pritchard: 1-35) Pero aquí no termina la historia.

En 1997, una experta en paleografía de la Biblioteca Folger Shakespeare reconoció la letra de Traherne en otro manuscrito anónimo (Smith: 
22-28). Ese mismo año, Jeremy Maule, de Trinity College, Cambridge, identificó un importante manuscrito de Traherne en la Biblioteca del Palacio de Lambeth que halló mientras buscaba otra cosa (Inge y MacFarlane: 14). Thomas Traherne, un nombre desconocido hacía cien años, cierra el siglo $\mathrm{XX}$ en un punto alto de los estudios literarios con un corpus que no deja de crecer.

La historia de los descubrimientos y los problemas iniciales de atribución, lograron, por un lado, que la obra de Traherne pasara casi automáticamente a ocupar un lugar dentro del canon literario y, por el otro, dieron origen a un problema de clasificación que hasta la fecha no se ha resuelto de manera satisfactoria. En las historias literarias se le agrupa usualmente con los poetas metafísicos ingleses, sin tomar en cuenta otros contextos que quizá sean más relevantes. Ciertamente se delata en su obra la influencia de autores anteriores, pero si se le estudia sólo en relación con ellos, existe el peligro de presentarlo como un expositor tardío de formas poéticas pasadas de moda, siendo que por el contrario, Traherne era ante todo un hombre de su tiempo.

Al ubicar a Traherne en el contexto de la literatura de devoción producida por sus contemporáneos, se vuelve evidente que en la Inglaterra de fines del siglo XVII existía una intensa preocupación cultural en torno al tema de la satisfacción individual, en la cual la religión se presenta como el medio de alcanzarla. Estaba muy difundida la creencia en que el poder del entendimiento era la herramienta fundamental en la búsqueda de la felicidad, entendida ésta en un contexto religioso como el único propósito de la existencia. Las obras de Thomas Traherne demuestran que él participó en este proyecto cultural, junto con muchos otros autores. La búsqueda de la felicidad, como se verá a continuación, era la médula de la educación religiosa, al grado que los conceptos de felicidad y religión a menudo parecen casi intercambiables. Existía todo un subgénero literario dedicado a fomentar la búsqueda de la felicidad, así como a orientar y aconsejar sobre los modos de conseguirla. Para esta sociedad, la felicidad no era un derecho, sino un deber.

Además de presentar este tipo de manual de la felicidad como contexto para estudiar la obra de Thomas Traherne, me propongo resaltar la función retórica de la materia suntuaria como una parte esencial del discurso religioso inglés del siglo XVII. La idea es presentar un contexto para el estudio de la obra de Traherne que ha sido casi ignorada hasta ahora. Traherne conoció a algunos de los autores que se incluyen en este trabajo, pero los más le eran desconocidos. Sin embargo, queda claro que comparten con él preocupaciones ideológicas importantes que reba- 
san incluso las divisiones sectarias que caracterizan la literatura de este periodo.

El tema de la felicidad y cómo alcanzarla es central dentro de toda la obra de Thomas Traherne. Al igual que otros promotores del llamado cristianismo práctico ("practical Christianity"), no se detiene en especulaciones abstractas, sino que insiste repetidamente que se trata de un asunto práctico que puede y debe ser estudiado, aprendido y aplicado, como cualquier otra área del conocimiento.

El ejemplo más claro lo encontramos en Select Meditations, el manuscrito comprado por James Osborn para la Biblioteca Beinecke de Yale, publicado apenas en 1997. En esta obra, Traherne presenta una lista de doce instrucciones: "Instructions Teaching us how to live the Life of Happieness [sic]" (Traherne, 1997: 69-72). Otro ejemplo to hallamos en el frontispicio de Commentaries of Heaven, la enciclopedia de la felicidad que fue rescatada de las llamas. Ahí anuncia que se propone descubrir los misterios de la felicidad y demostrar que todas las cosas son objeto de ella (Traherne, Add. MS 63054, fol 2r.). En un célebre pasaje de su obra más reconocida, Centuries of Meditations, cuenta la historia notable de su propia vocación: "When I came into the Country and being seated among silent Trees, had all my Time in my own Hands, I resolved to spend it all, whatever it cost me, in search of Happiness, and to Satiat that burning Thirst which Nature had enkindled, in me from my Youth" (Traherne, I, 1958: 137). ${ }^{1}$

No sólo eso, en la introducción de Christian Ethicks, libro publicado en 1675, un año después de su muerte, afirma que ha logrado su cometido, aunque sólo después de "many years of earnest and diligent study" (Traherne, 1675: 3).

Afirmar que la felicidad se pueda estudiar y aprender sonará dudoso a los oídos modernos, evocando acaso imágenes de libros de autoayuda para gerentes empresariales. No obstante, en el siglo XVII el subgénero de las guías de conducta quedaba comprendido dentro de la literatura de devoción oficial, no sólo escrita sino aprobada y fomentada por los modelos de la respetabilidad y de la credibilidad: miembros de la iglesia y doctores en teología.

En lo que constituye sin duda el periodo de máximo fervor religioso de Inglaterra, y también el de mayor tensión entre facciones rivales, los miembros de los distintos grupos parecen coincidir, en tanto que mu-

\footnotetext{
${ }^{1}$ Al citar textos antiguos se ha conservado la ortografía original, lo mismo que el uso de mayúsculas e itálicas.
} 
chos de ellos escriben manuales de la felicidad. Existió una gran proliferación de instructivos, sermones y tratados escritos por ministros y maestros universitarios, que cedían al individuo la responsabilidad de lograr su propia felicidad, siguiendo, claro está, el camino de la religión. He aquí algunos títulos de libros publicados entre 1655 y 1709 que reflejan esta tendencia: The Way to True Happiness (Ralph Venning, 1655), The Art of Happiness (Francis Rous, 1656); A Discourse about the state of True Happinesse (Robert Bolton, 1656); The Way to Bliss (Elias Ashmole, 1658); The Crown and Glory of Christianity, or Holiness, the Only Way to Happiness (Thomas Brooks, 1662); The Art of Contentment (Anon., 1675); The Happy Ascetick (Anthony Horneck, 1681); Enquiry after Happiness (Richard Lucas, 1685); Jacob's Vow or Man's Felicity ad Duty (John Cockburn, 1686); Directions How to be Content (Isaac Barrow, 1704), y A Gentleman Instructed in the Conduct of a Virtuous and Happy Life (George Hickes, 1709).

Los manuales de la felicidad, sin embargo, no existen como categoría aparte. Constituyen un grupo relativamente conspicuo dentro de los libros religiosos en general. En el siglo XVII, los libros de religión eran sumamente importantes para el negocio de los libros. En el periodo de los Estuardo, las obras religiosas ocupaban la mayor parte del total de las ediciones nuevas. Hacia 1640, el $42 \%$ de los títulos correspondía a obras religiosas. Veinte años después, en 1660 , cuando el vendedor de libros, William London, publicó el segundo suplemento de su Catalogue of the Most Vendible Books in England, los libros de teología eran la categoría más grande e importante. London llega a ciertos extremos para explicar cómo él mismo se ha beneficiado del estudio de tales obras, y que su costo es una bicoca comparado con las riquezas que contienen.

The Knowledg of God [is] the Summum bonum, the chiefest of studies, which indeed is superlatively above all. [...] This is the knowledg that speeds our passage to Eternal Glory, that is the shortest cut to Immortal Happiness... [The] Knowledg of God in Christ is the Philosophers Stone in Divinity; by it we may turn all events into golden advantages to our souls. [...] The many advantages now in print, by Learned, Reverend and Holy Ministers will be one day a witness against such as make it nor their chief study to train up themselves and relations therein. It should be our duty to hug our selves, and rejoyce in the multitude of Gods mercies, wrapt up in these gracious advantages, and pious helps. The times are glutted with precious conveniences of the Gospel, by Preaching and Books... (London, sig. D2r.). 
Es interesante observar que London no solamente presenta los libros de religión o Divinity como un atajo para lograr la felicidad, sino también el hecho de que utiliza imaginería suntuaria para anunciar su producto. Habla, por ejemplo, de promesas doradas y preciosas. A partir de su reprimenda para quienes no hacen de la religión su principal interés, se infiere que este tipo de publicación respondía a una demanda nacida de condiciones sociales específicas en las cuales el descuido del estudio de la religión equivalía a una falta al deber cívico.

Los libros de religión variaban considerablemente en cuanto a su propósito se refiere. Entre los tipos principales encontramos libros de oración, de salmos, catecismos, sermones impresos, tratados, meditaciones, paráfrasis bíblicas en verso, panfletos moralizantes y manuales de devoción. Los manuales de santidad (designada por vocablos diversos tales como "godliness", "blessedness", "saintliness", "holiness") casi invariablemente ofrecen el señuelo de la felicidad como la máxima recompensa de su estudio. Tales manuales están íntimamente relacionados con los libros para remediar el descontento. Muchos autores escribieron tanto libros de la felicidad como manuales de remedios, a veces de manera separada, a veces combinada. Esta observación es importante en tanto que hace aflorar la inevitable contigüidad entre los dos subgéneros, como dos lados de una misma moneda. La sutil diferencia de enfoque transmitida por el título sirve para canalizar las expectativas de modos distintos. Los libros de remedios espirituales se dirigen de manera explícita a los afligidos, rechazados, deprimidos o enfermos, que tienen necesidad de una ayuda más urgente. Es habitual que los autores utilicen terminología médica de manera metafórica para aplicarla a asuntos espirituales, y desarrollarla en mayor o menor grado. En tales casos, el autor se presenta como el médico que ofrece alguna cura doctrinaria para los males espirituales. Su punto de partida es la descripción de alguna carencia en los distintos aspectos de la vida, carencia descrita casi invariablemente como fruto de lo que ellos llaman "la maldad de los tiempos" ("the wickedness of the times"). Los remedios son intentos de compensarla.

En The Soul's Conflict with Itself, por ejemplo, el puritano Richard Sibbes escribe: "There is an art [or] skill of bearing troubles, if we could learn it without overmuch troubling ourselves, as in bearing a burden there is a way so to poise it that it weigheth not over heavy; if it hangs all on one side, it poises the body down" (Sibbes: 148).

$\mathrm{Y}$ es precisamente el factor aprendizaje lo que más importa en este tipo de texto, porque se basa en la creencia filosófico-religiosa en la perfectibilidad del ser humano. La felicidad, o al menos el contentamiento, 
se describe una y otra vez no como un estado, sino como un arte, es decir, como un conocimiento que se debe aprender. Las guías ponen el énfasis en la meta más que en el punto de partida. Aun así, también se basan en la idea de que la caída del hombre ha colocado a la humanidad en una posición de disminución o pérdida que sí puede ser superada por medio del entendimiento. En un mundo ideal, todos aprenderían este arte.

En tanto que muchas de estas guías fueron escritas por ministros y teólogos educados en la universidad para quienes la virtud y el cristianismo seguían siendo sinónimos, existía ya una tendencia secularizante y racionalista incluso entre los autores más ortodoxos. Esto lo demuestra el hecho de que se estipulaban deberes separados para asuntos religiosos y mundanos para que el individuo pudiera alcanzar la felicidad. El tema era tan popular, que incluso Thomas Hobbes le dedica un pasaje de Leviathan, y es un pasaje crucial. Las implicaciones de su negativa a tratar cuestiones éticas en un contexto religioso, incluyen la negación tácita de la mera posibilidad de aprender o estudiar para ser feliz. El descontento endémico es natural a la humanidad. Su premisa inicial es que todos los hombres son iguales por naturaleza.

From this equality of ability ariseth equality of hope in the attaining of our ends. And therefore if any two men desire the same thing, which nevertheless they cannot both enjoy, they become enemies, and in the way to their end, which is principally their own conservation, and sometimes their delectation only, endeavour to destroy, or subdue one another. And from hence it comes to pass that where an invader hath no more to fear, than another man's single power if one plant, sow, build or possess a convenient seat, others may probably be expected to come prepared with forces united to dispossess, and deprive him, not only of the fruit of his labour, but also of his life, or liberty. And the invader again is in the like danger of another (Hobbes: 61-62). ${ }^{2}$

La felicidad sólo se infiere aquí de manera indirecta, en los conceptos desencantados de "conservation" y "delectation". Y es la búsqueda misma de donde se deriva la miseria humana. Burdamente dicho, la búsqueda de la felicidad es lo que provoca la infelicidad. Para Hobbes, la felicidad no tiene nada que ver con la virtud, el esfuerzo personal o la capacidad de

${ }^{2}$ Las itálicas son mías. Nótese ya la relación entre la felicidad y la seguridad de la pertenencia que se explica más adelante. 
aprendizaje. La define como una pasión más, como "the continual success in obtaining those things which a man from time to time desireth" (Hobbes, 23). Constituye meramente la prueba de que el hombre es el esclavo de sus apetitos. Para él, el aprendizaje está determinado lingüísticamente, y sólo el más estricto de los métodos puede extirpar los errores de la fe ciega y cegadora, e incluso entonces la certeza sería relativa.

Los autores de guías para ser feliz rechazan de modo enérgico las implicaciones de Hobbes. Este filósofo encarna múltiples preocupaciones históricas de una moralidad que se sentía amenazada. Refutar las ideas de Hobbes se convirtió en un ejercicio retórico habitual para los representantes de la iglesia oficial; es un tipo de texto que abunda tanto en tratados científicos como morales. La ironía es que Hobbes ayudó sin querer a definir la posición de sus adversarios. A pesar de sus protestas, no cabe la menor duda de que frente al racionalismo secular, los campeones de la virtud sintieron la necesidad imperativa de justificar la fe por los mismos medios racionalistas de Hobbes, produciendo argumentos lógicos acerca de la compatibilidad de la religión con el parámetro de la razón. El papel de la razón para lograr la felicidad hubo de ser redefinido para dejar claro que ésta sí se podía estudiar y aprender.

En An Account of Virtue, el neoplatónico Henry More, escribe lo siguiente:

[Marcus Aurelius has said that] to act according to Nature or according to Reason, is in a rational Creature the same thing. Wherefore all pravity is repugnant to human Nature. But that Virtue is natural to human Nature, born as a Twin therewith, is manifest, as well because Man's Soul is a rational Being, as because Righteousness or perfect virtue (as we are told by divine Revelation) is irrational; and that it was Sin only that brought Death into the World. For since the State of Innocence was to have been eternal, this plainly shews, that such a state was most perfect and most natural. And therefore that Restitution unto such a State must be the most intrinsick and peculiar Pleasure (More: 6 ). ${ }^{3}$

Define la felicidad como "that pleasure which the mind takes in from a Sense of Virtue, and a Conscience of Well-doing; and of conforming in all things to the Rules of both" (More: 4-5). Lo que él llama "conscience of well-doing" (la conciencia de hacer el bien), es la traducción de la ac-

\footnotetext{
${ }^{3}$ Compárese con Milton, Paradise Lost I, 1-3.
} 
tividad racional a la acción, factor crucial para la concepción de la felicidad de Traherne, como la prueba de que sí puede ser aprendida. Pero Traherne es más cuidadoso que More al describir la relación entre razón y religión. Explica en Christian Ethicks:

The very same Object that is known to Reason, may by Faith be believed: Reason not destroying but confirming Faith, while it is Known upon one account, and believed on another. For there is a Mutual Convenience between these two, Faith is by Reason confirmed, and Reason is by Faith Perfected (Traherne, 1675: 225).

En tanto que subraya la compatibilidad entre las dos partes del argumento, Traherne establece la distinción entre saber y creer. Al mismo tiempo, implica que la razón es meramente instrumental para la religión y no un fin en sí misma. Por eso existen tantas instancias en las que la razón se presenta como servidora de la religión, y no como su sustituto. El aspecto más importante, sin embargo, consistirá en armonizar las dos cosas. En este caso, el aprendizaje sería aquella acción (o acto de fe) mediante la cual se efectúe una apropiación racional, operación que Traherne define repetidamente como "right apprehension" (aprehensión correcta). Según esto, sin fe no habría acción; el aprendizaje racional por sí solo aún padece cierta ceguera.

Desde esta perspectiva, es mucho más comprensible por qué Isaac Barrow, famoso predicador que apoyaba la causa real, muy admirado por Traherne, afirma que la virtud

[...] is an art, with which we are not born, no more than with any other art or science; the which, as other arts, cannot be acquired without studious application of mind, and industrious exercise. [... Content] is certainly a most excellent piece of learning; most deserving our earnest study: no other science will yield so great satisfaction, or good use; all other sciences, in comparison thereto, are dry and fruitless curiosities (Barrow, 1685: 43-44).

Para ensalzar el valor de este aprendizaje, los maestros de felicidad casi invariablemente utilizan la retórica del lujo y los tesoros. Para ellos, la riqueza de conocimientos era una riqueza real y práctica. Por otra parte, la inclusión de ciertas palabras, sobre todo en los títulos de estos libros, se puede interpretar como la sublimación de los objetos evocados. Desde los modestos panfletos de devoción, plegarias y meditación, hasta los grandilocuentes sermones, tratados y guías de la felicidad, todos es- 
tán decorados con la imaginería de tesoros, metales y piedras preciosas, además de coronas, cetros y demás parafernalia real, en un afán de dejar perfectamente asentado cuál es el verdadero valor de su doctrina.

Uno pensaría que las iglesias reformadas y las sectas que de ellas se derivaron procurarían por todos los medios no compartir con la Iglesia romana el gusto por los lujos ceremoniales, que fue de hecho una de sus principales protestas. Para poder transmitir su mensaje con fuerza, sin poner en juego su aspiración por la ortodoxia y la austeridad de los primeros cristianos, los teólogos reformistas parecen haber abstraído las riquezas materiales de la iglesia corrupta para incorporarlas a su discurso dentro de un ámbito espiritual y trascendente. La riqueza que prometen, insisten, es incorruptible, pura, imposible de robar, segura, etc. La simple premisa del neoplatonismo cristianizado de que la verdadera riqueza de la humanidad está en el reino de los cielos se amplifica en estos textos un sinfin de veces, y con gran lujo de detalle.

He aquí algunos ejemplos: un autor dice que los Evangelios son preciosos y que Cristo es un tesoro infinito (Grosse, sif. A, r.); otro pide plata y oro (espirituales) para el templo de Dios (Vaughan: 35); otro, imagina lujosos géneros "Blue and Purple, and Scarlet, and fine Linen for the Tabernacle of the New Jerusalem" (Jackson: 202); otro más afirma que la proximidad con Dios nos enriquece y nos da derecho a los tesoros más incalculables (Gale, sig. A2, v.; Barrow, 1680: 60). El predicador puritano, Thomas Brooks, quien supera a todos en el profuso empleo de estas imágenes, eligió los siguientes títulos para sus libros: Precious Remedies against Satan's Devices, Apples of Gold, String of Pearls, The Crown and Glory of Christianity, The Privie Key of Heaven, A Cabinet of Choice Jewels, Unsearchable Riches y A Golden Key to Open Hidden Treasures. ${ }^{4}$

El uso de la imaginería suntuaria y la promesa de inmensas ganancias son, en primer lugar, de origen bíblico; pero forman parte también de una estrategia retórica y pedagógica cuya intención es despertar el interés del público o lector por las cuestiones religiosas utilizando un señuelo que en la época tenía una poderosa carga significativa. En la epístola dedicatoria al obispo de Lincoln, Anthony Horneck, autor de The Happy Ascetick, se lamenta diciendo que "Religion, like the Poets Eccho, is become an empty sound" y que es la misión de los teólogos y los predicadores intentar por todos los medios posibles volver a poner de moda la fe: "to bring

\footnotetext{
${ }^{4}$ Estas obras se escribieron y publicaron entre 1652 y 1675 , a excepción de Unsearchable Riches, que se publicó hasta el siglo XIX. Hay unas cincuenta ediciones de las obras de Brooks.
} 
that Faith into fashion again, which formerly, when times were better, discovered it self in suitable Works and Actions" (Horneck, sig. A2r.).

No cabe la menor duda: la retórica de la riqueza era una tendencia aprobada y generalizada, tanto entre los miembros de la iglesia oficial como entre los disidentes separatistas. Los maestros de felicidad a menudo adoptan estrategias publicitarias para vender mejor su producto. William London, el librero, insiste que su catálogo está cargado de riquezas, y que su mercancía es mejor que el oro fino, y que ninguna cosa deseable se le compara (London, sig. [C4, r.], D2r.).

El discurso de la felicidad estaba inextricablemente ligado al discurso de la riqueza. Este hecho se vislumbra con más claridad al observar qué es lo que presentaban como la raíz del problema, es decir, las causas del descontento. Uno de los rasgos que reaparece con mayor regularidad tanto en los libros de la felicidad como en los de descontento es la enumeración de las causas de la infelicidad, con sus correspondientes curas. Isaac Barrow, por ejemplo, presenta una larga lista de causas que incluye deformidad, enfermedad, bajeza de cuna, servidumbre, encarcelamiento, destierro, dolor, envidia, odio, amor propio, muerte, traición, calumnia, difamación, injusticia, fracaso en los proyectos, amigos ingratos y fortuna adversa (Barrow, 1685: passim). Algunos de estos temas, o variaciones de ellos, siempre se toman en cuenta. No obstante, no cabe duda de que la causa de descontento más frecuente y más estudiada es en estos textos la carencia o pobreza.

La injusticia social de la pobreza casi nunca la discuten estos autores religiosos más allá de la recomendación de la caridad. La fama de Isaac Barrow como predicador se consolidó después de su sermón "Of the Duty and Reward of Bounty to the Poor", en el cual describe la gloria del hombre caritativo, y presenta el dilema de los pobres con gran compasión y lucidez. A diferencia de los libros de remedios, sin embargo, este importante sermón está dirigido a los ricos. De hecho es una exhortación a la dádiva. Los pobres sólo están presentes de nombre.

Ocasionalmente en estos textos se suscita alguna crítica amarga de la injusticia humana, pero este tipo de comentario suele ser bastante inofensivo para el estatus quo.

Cuando sí abordan el tema, sin embargo, los teólogos traen a cuento una doctrina básica del cristianismo, casi siempre citando a San Pablo: "I have learned in whatever state I am therewith to be content". ${ }^{5}$ Casi siem-

${ }^{5}$ Filipenses 4.11. Tomo la cita del frontispicio de Isaac Barrow, Of Contentment.... 
pre se pone énfasis en la diferencia entre las circunstancias cambiantes del mundo terreno y la inmutabilidad de los premios celestiales. En la mayoría de los casos se recomienda la renuncia a la felicidad terrena a favor de una felicidad futura. El mundo se presenta como un valle de lágrimas que debe ser soportado con resignación y paciencia. No obstante, sí ofrecen un remedio temporal para este mal: la moderación o regulación del deseo.

Barrow, por ejemplo, explica que San Pablo "did not desire or lack more than what God had supplyed him with; had put into his hand or had set within his reach; that his will did sute his state, his desire did not exceed his power" (Barrow, 1685: 3). El muy erudito Theophilus Gale recomienda: "Bring your natural desires into a narrow compass, but let your hearts be enlarged towards God: amuse not your hearts as children at the glistering outside of things; but feare a snare in every comfort; feed much on Spiritual delights that will kill carnal pleasures" (Gale, 1676: 85).

La sustitución de los bienes terrenos por los celestiales es ciertamente un lugar común. Sin embargo, para comprender las implicaciones de tal sustitución hay que tener en cuenta qué entendían por deseo. En The Art of Contentment se describe de este modo:

[...] a sickness of the mind, a perpetual gnawing and craving of the appetite without any possibility of satisfaction: and indeed [it] is the same, in the heart, which the Caninus appetitus is in the stomach, to which we may aptly enough apply that description we find in the Prophet, he shall snatch on the right hand and be hungry, and he shall eat on the left and not be satisfied, [Esay.9.20] Where this sharp, this fretting humor abounds, nothing converts into nurishment: every new accession do's but excite some new desire... (Anon: 12).

Otros lo describen como una sed avara e insaciable de bienes inferiùres o como una gangrena en el alma que consume los afectos naturales con un calor venenoso hasta llenarnos de humores virulentos (Gale, 1676: 71; Charron: 75). En estos ejemplos queda en evidencia la asociación del deseo con los impulsos irracionales, especialmente en su modalidad devoradora o consumidora que se caracteriza por una insaciabilidad destructiva. No obstante, ya que dicha insaciabilidad es inherente a la condición humana, el único modo de superarla es, según estos textos, por medio de la sustitución de los objetos mundanos por objetos más elevados. Una vez purgado, el deseo virtuoso tiende hacia los objetos celestiales y así se 
ve premiado con satisfacción duradera. Teólogos y filósofos llegan a ciertos extremos para tratar de describirla. El neoplatónico Henry More explica: "the Boniform Faculty of the Soul: [is ...] that part of the Will which moves towards that which we judge to be absolutely the best..." (More: 6).

More intenta aquí dar una explicación científica de los posibles motores de la voluntad. El factor movimiento en este caso se deriva de su veta neoplatónica, pero otros maestros de la felicidad con distinta formación también lo utilizan. La descripción de Theophilus Gale también tiene un timbre científico:

Look as in nature there is a Centre of Gravity unto which all ponderous weighty bodies by their Gravity and weight naturally tend; So in corrupt Nature, Love to the world or Concupiscence is that lustful Pondus, or weight whereby the heart is violently impelled and inclined towards the world, as its Centre of Gravity...

Contraries illustrate each other: and love to God moves in the same manner as love to the world moves. So that to love God is to transfer the Actions and Passions of our Love from the world to God, as our last end and chiefest Good. In short, the love of God implies a superlative preference of God above all lower Goods [Luke, 14.26]. A Divine Weight or Bent of heart towards God, as our Centre [Deut, 6.5] (Gale, 1676: 70, 74).

Richard Lucas, oficiante de Westminster, utiliza un lenguaje que nos recuerda el Cantar de los cantares para describir lo mismo. El opta por hablar de celo, "zeal", que define como "that solid, spiritual and operative Religion, which may be felt and enjoy'd by us our selves, in [...] the longings and Breathings of Pious Desires..." (Lucas, 1696: 494). Es importante hacer notar la concatenación paradójica de "solid" y "spiritual", que se resuelve en su facultad operativa. No se trata de un celo farisaico, sino de un celo que en apariencia es vehemente y genuino, que se puede sentir y corroborar por medio de las señales del amor piadoso ("longings and Breathings"), que de algún modo incorporan el factor movimiento a la definición de Lucas.

Barrow trata el tema de manera más exhaustiva:

[Love is] an Affection or Inclination of the soul toward an Object, proceeding from an Apprehension and Esteem of some Excellency or some Conveniency therein (its Beauty, worth, or Usefulness) producing thereupon, if the Object be absent or wanting, a proportionate desire, and consequently an endeavour to obtain such a propriety 
therein, such a possession thereof, such an approximation or union thereto, as the thing is capable of (Barrow, 1680: 6-7).

Su definición es muy formal y filosófica. Utiliza un lenguaje analítico y racionalista que tiene muy poco que ver con el concepto Hobbesiano del apetito, y que ciertamente da por hecho la idea del alma. La facultad boniforme de More se describe aquí como un afecto o inclinación del alma. Sin embargo, lo que importa de la definición de Barrow para nuestros propósitos, es la inclusión de dos elementos adicionales al movimiento: el primero es la causa misma de la inclinación ("an Apprehension or Esteem of some Excellency or Conveniency therein") y el segundo es su efecto ("an endeavour to obtain [...] propriety therein"). Puesto que estas dos consideraciones son cruciales para comprender la obra de Traherne, las veremos con mayor detalle.

Debemos aquí recordar que el concepto de pobreza se explicaba a menudo como falta de discernimiento o error de juicio. En Pseudodoxia Epidemica, Sir Thomas Browne define el error como "a false judgment of things, or an assent unto falsity [caused by] perverted apprehensions" (Browne: 15). Existía la creencia de que si esa carencia fundamental o error se corrigiera, la aprehensión correcta ("right apprehension") que de allí se derivara no podría sino recanalizar el deseo hacia un objeto verdaderamente provechoso, y en consecuencia conducir a la felicidad.

En el discurso religioso del siglo XVII inglés, la búsqueda de esta "aprehensión correcta" o plenitud del discernimiento es lo que conduce a la riqueza espiritual y descubre el secreto de la felicidad. En las explicaciones con frecuencia se alude al sentido de la vista. Así como la melancolía se explica como la percepción de la realidad a través de un vidrio oscuro, la aprehensión correcta es la realidad vista a través del más límpido cristal. Thomas Jackson subraya el papel de la imaginación visual concebida como el intelecto activo. Barrow escribe que uno de los modos más importantes de estudiar la felicidad es por medio de "attentive consideration upon the divine Perfections, with endeavour to obtain a right and clear apprehension of them". Y recomienda: "We should not be so dull in apprehending or so slack in performing duty, for this sharp-sighted affection would presently discern, would readily suggest it to us; by the least intimation it would perceive what pleaseth God" (Jackson, 1625: 98; Barrow, 1680: 41, 25). Si nos basamos en estas premisas, el camino de la felicidad es el camino de la filosofia, como insiste Richard Lucas: "nothing but industrious Reason, pure and vigorous Philosophy, can e'er attain it. The Sluggard or the Wanton, the Fool and Vain may have some Fits of 
Ease and Mirth, [but] only the Rational, only the Philosopher can possess true and lasting Happiness" (Lucas, 1685: 38-39).

La verdadera felicidad, por lo tanto, procede de la certeza de la posesión. No puede haber posesión ni dominio ni control sin madurez intelectual, lograda sólo a través de la razón ("industrious Reason"). Lograr la aprehensión correcta es alcanzar la madurez del entendimiento. Francis Rous compara este poder con una mano:

In vain it is that there is an hand stretched out to deliver this happiness to us, if we have not also a hand to receive it. For if there be any happiness, and an offered happiness, if we receive it not, if we have no property in it, we continue in misery, even in the sight of happiness. We are not happy, except happiness be ours (Rous: 39 ).

La correcta aprehensión equivale a una apropiación mental que es un paso hacia la acción concreta. Barrow lo describe como el intento de adueñarse del objeto ("an endeavour to obtain... propriety"). La apropiación mental casi invariablemente se expresa en términos de títulos de propiedad y posesión cuando estos autores describen la satisfacción del deseo virtuoso o religioso, es decir, la felicidad. El discurso de la posesión es típico. George Fox, fundador de la secta cuáquera, utiliza el término "posesión" de manera enfática para distinguir entre cristianos auténticos y cristianos hipócritas. En un breve tratado titulado Possession above Profession, sostiene que la profesión del cristianismo no basta, que para que alguien pueda llamarse cristiano con pleno derecho, antes debe poseer a Dios.

[...] common Reason teacheth this, That if a Man buy a Horse, or Sheep, or other Cattel, and give or pay a Price for them, the Horse and Cattel are his own Use, and Service and Command [...] and to be ordered and fed by him... this the common Reason of every earthly selfish Man understands (Fox: 17).

Sin embargo, el uso que hace del término delata una contradicción aparente puesto que más adelante invierte la relación afirmando que es Dios (Cristo) quien posee al hombre.

[...] we are [Christ's] and not our own, and are at his ordering and disposing by his Heavenly Power; and he orders us heavenly Milk, and Wine and Honey, and heavenly Bread \& Water, and the heavenly Cloathing, the Fine Linen that he clothes us with, and feeds us in his Heavenly Pastures of Life, his Lambs and his Sheep (Fox: 18). 
El razonamiento sería el siguiente: puesto que Cristo es superior al hombre, él debe ser el propietario, el amo de las criaturas que compró con su sacrificio. Pero como el hombre está capacitado para elegir a Dios como el objeto de su deseo, entonces se puede decir que él a su vez lo posee. Los argumentos suelen enredarse de este modo. Incluso el menos controversial Isaac Barrow se mete en algunos vericuetos para explicar las implicaciones de la relación entre dueño y objeto:

\begin{abstract}
When we stand upon such terms with any person, that we have a free access unto and a familiar entercourse with him; that his conversation is profitable and delightful to us; that we can upon all occasions have his advice and assistance; that he is always ready in our needs, and at our desire to employ what is in him of ability for our good and advantage, we may be said to own such a person, to possess and enjoy him; to be tyed (as it were) and joined to him (Barrow, 1680: 11).
\end{abstract}

Si uno tuviera que elucidarlo, entonces la posesión se definiría en estos textos como un concepto, como un conocimiento que, una vez logrado, no puede evitar expresarse en toda acción externa. En ese sentido, constituye todo aquello que estos autores llaman tesoro, todas las joyas de sus textos serían inútiles sin la posesión real expresada en la vida misma.

El llamado a la acción en las guías de la felicidad siempre es explícito e imperativo. The Art of Contentment define la cristiandad como el arte de la vida feliz (Anon: 3); Richard Lucas define la vida como "The Rational Exercise and Employment of our Powers and Faculties [towards] Perfection" (Lucas, 1696: 2); para Thomas Brooks "Doctrine is but the drawing of the bow, application is the hitting of the mark" (Brooks, 1662, sig. D3, v.); Henry More afirma que "the true Design of all, who write of Morals, is, or ought to be, for amendment of Life" y define la ética como el arte de vivir bien y felizmente (More, sig. A4r.). Según Samuel Gott, "Bare learning though of the best kind, is but a map of Happiness, and no Real felicity" (Gott, 1650, en London, sig. D, r.); Theophilus Gale define la beatitud como "the operation of the rational Soul according to the best virtue in a perfect life" y recomienda la eupraxia, es decir, la práctica del bien o buena conducta para alcanzar la felicidad (Gale, 1670: 386-387).

Esta insistencia es parte del esfuerzo generalizado de suplir la frialdad de los medios impresos. Los maestros de la felicidad se esmeran en instruir a sus lectores sobre el modo en que deberían leer los manuales. Thomas Brooks hace una minuciosa disección del acto de leer para revelar las múltiples acciones que conlleva una lectura ideal, para quien real- 
mente desea lograr el objetivo. En $A$ Golden Key to Open Hidden Treasures, escribe:

Reader, if thou wouldest make any earnings of thy reading this Treatise, then thou must, 1 . Read, and believe what thou readest; 2 . Thou must read, and meditate on what thou readest: 3 . Thou must read, and pray over what thou readest: 4 . Thou must read, and try what thou readest, by the touchstone of the word: 5. Thou must read, and apply what thou readest; that plaister will never heal, that is not applied... 6. Thou must read, and make conscience of a living up to what thou readest, and of living out what thou readest; this is the way to honour thy God, to gain profit by this Treatise, to credit Religion, to stop foul mouths, to strengthen weak hands, to better a bad head, to mend a bad heart, to rectifie a disorderly life, and to make sure work for thy soul, for heaven, for eternity.

Reader, In a fountain sealed, and treasures hid, there is little profit or comfort, no fountain to that which flows for common good, no treasures to those that lie open for publick service (Brooks, 1675: sig. B3, v.).

La vida práctica es el único lugar donde se pueden medir los avances de este estudio. Por lo tanto, se requiere una lectura activa, porque sólo siendo activo puede un lector ser más receptivo. Tal es la paradoja del verdadero estudio, que, desde la perspectiva del maestro, queda redondeada por la paradoja de los manuales mismos: su justificación yace en su obliteración. Sólo se puede demostrar que sirvieron cuando ya no se necesitan.

Aquí reside la diferencia fundamental entre Thomas Traherne y los demás autores mencionados, que escriben desde el punto de vista del maestro, instruyendo y adoctrinando. Rara vez tratan los temas de manera personal y, cuando lo hacen, ninguno anuncia de manera explícita que ha logrado la meta que promueve. En cambio, Traherne escribe no sólo como un maestro, sino como alguien que vive la felicidad, como alguien que ha leído y, retomando las condiciones de Brooks, creído, meditado, orado, probado, aplicado y vivido las cosas que dicen los libros. En términos de George Fox, no es un profesor sino un poseedor de la felicidad. En Centuries of Meditations Traherne escribe:

I evidently saw, that the Way to becom Rich and Blessed, was not by heaping Accidental and Devised Riches to make ourselvs great in the vulgar maner, but to approach more near, and to see more Clearly with the Ey of our understanding, the Beauties and Glories of the 
whole world: and to hav communion with the Diety in the Riches of GOD and Nature.

I saw moreover that it did not so much concern us what Objects were before us, as with what Eys we beheld them; with what Affections we esteemed them, and what Apprehensions we had about them. All men see the same Objects, but do not equaly understand them. Intelligence is the Tongue that discerns and Tastes them, Knowledg is the Light of Heaven. Lov is the Wisdom and Glory of GOD. Life Extended to all Objects, is the Sence that enjoys them. So that Knowledg Life and Lov, are the very means of all Enjoyment. which abov all Things we must seek for and Labor after (Traherne, 1958, I: 149-150).

Discernir es ser rico. Así como la pobreza es un estado de ignorancia, la riqueza es un proceso de conocimiento que sólo puede aumentar. Es importante subrayar el hecho de que no es una cuestión de relativismo; no está diciendo que la belleza está en los ojos de quien la mira. Traherne presenta su visión como un descubrimiento objetivo para beneficio de toda la humanidad. Hobbes escribió que en el estado de guerra no había propiedad ni dominio, "no mine and thine distinct; but only that to be every man's that he can get for so long as he can keep it" (Hobbes: 62). Desde el punto de vista de Traherne, la desaparición del "mío" y el "tuyo" ("mine and thine") no es el producto desgraciado del saqueo, el despojo y la violencia, sino el dichoso resultado de la aprehensión correcta. Escribe:

Sweet Apprehensions strangly caus objects to vary [...] To some the world is a kingdom, to others a Dungeon a wilderness a prison. Because some have pure and bright Apprehensions, others rude and vulgar and Deformed. when a Begger goes by a Noble Mans house what is the reason He sees all the splendor Beauty and magnificence with So Cold an Ey!

He Apprehends it not with any Pleasure,

His onely is the Joy whose is the Treasure.

But palaces and Treasure, which Noble men more sweetly Apprehend are truly theirs, so are the Heavens and all Things truly mine. True Apprehensions being always Best, becaus Nothing can truly be Appr[e]hended but it must needs be Aprehended as Treasure and Inter[e]st. Becaus evry thing to God and his Image is soe. Truth and felicity are ever the same, becaus all the things in Heaven and Earth are Infinit Treasures: And are never Enjoyed but when truly Seen: nor ever indeed truly seen, but by a wise man they are truly enjoyd (Traherne, 1997: 51). 
De esto se colige que no es simplemente cuestión de poseer, sino de poseer lo más valioso. Lo que es tan notable de la visión de Traherne es que el tipo de posesión que describe no impide que otros sean simultáneamente poseedores del mismo objeto. Cruza las fronteras entre lo mío y lo tuyo, entre el yo y el otro, por medio del lenguaje de su "aprehensión", como se resume en los siguientes versos de "Shadows in the Water":

I, my Companions, see

In You, another Me.

They seemed Others, but are We;

Our second Selvs those Shadows be.

(Traherne, 1958, II: 129)

Isaac Barrow explica la paradoja en términos de caridad cristiana:

Charity hath a good eye, which is not offended or dazzled with the luster of the neighbour's vertue, or with the splendour of his fortune but vieweth either of them steadily with pleasure, as a very delightful spectacle... Its property is to rejoice with them that rejoice [Rom. 12.15] (Barrow, 1680: 145).

Al poner a Barrow al lado de Traherne se aprecia mejor la diferencia que existe entre un profesor y un poseedor de la felicidad. El uno habla con claridad pedagógica, mientras que el otro ha sintetizado un vasto conocimiento en una forma más personalizada o "apropiada", a menudo derivada de alguna paradoja. Barrow nos presenta una interpretación digerida pero analítica de las Sagradas Escrituras, mientras que Traherne integra las dos posiciones, aunque pone el énfasis en cómo la experiencia personal le ha permitido confirmar la veracidad de lo que dicen los libros.

La aprehensión correcta de Traherne es, explícitamente, un modo de ver, pero es también un modo de nombrar, una especie de enunciación que produce verdad en el momento mismo en que ocurre. El aspecto reiterativo e insistente de su discurso puede ser visto como un método para reafirmar un logro existencial. En este sentido, su obsesión con ciertas palabras e ideas refuerza la intención comunicativa para producir la impresión de que él en lo personal ha logrado realmente aquello que prometió por el mismo medio. La calidad vibrante y vital de los libros de devoción culmina de manera única en la obra de Traherne, que a su vez les confiere grandeza al celebrar su propio éxito.

La comunicatividad es la mejor prueba de la felicidad. El neoplatónico Nathanael Culverwel escribió: "It is the very nature of goodnesse to diffuse 
it self abroad in a spreading and liberal manner; for it does not thus lose any thing, but augments, and increases its being by communicating it self" (Culverwel: 86). Y Thomas Brooks: "The better any thing is, the more communicative it will be, for bonum est sui communicativum" (Brooks, 1654, sig. [A3, r.]). Francis Rous reitera: "[It is] not the being but the communication of happiness [that] makes us happy" (Rous: 39 ). Por su parte Traherne, en tanto que se lamenta porque la humanidad reprime el impulso comunicativo en este mundo, afirma que en el cielo "it is the joy of all to be Communicativ, and He most Happy that is Infinitly So" (Traherne, 1997: 91). Sin embargo, aun cuando comparte con los demás teólogos las mismas aspiraciones y las expresa en el mismo lenguaje, el poder comunicativo de sus palabras se somete a una prueba extrema cuando afirma que su estudio de la felicidad ha dado resultado. Entre los demás, es el único que concluye, después de la lista de "Instrucciones" citada al principio de este ensayo, que:

The seeds of all wisdom Happines and Glory are here Included. And these Instructions So Great, that I would have given in my childhood Millions of worlds to have met with one teaching them, so earnestly did I Long after them. How much therfore am I bound to Bless God for having Satiated my soul and Replenished me with Good Things. It makes us see the face of Religion as Bright as the Sun, as Fair as the Heavens, as Real as the world.

It Discovereth an Infinit weight and Depth of concernment in evry work in evry Person. And Lifts a Holy Man above Thrones and Kingdoms, as much as Stars are above Sands or Angels above Pismires.

It maketh a man at home in his own kingdom. And even as a Pilgrim here to Liv in Heaven.

It Sheweth the Infinit Dreadfullness of any crime: and with what profound affections we ought on all occations to walk with God.

It Shews the infiniteness of the Love of God in the contemplation of which we ought to Liv for ever (Traherne, 1997: 71).

Para concluir, si retomamos la idea de que no es el ser feliz sino la comunicación de la felicidad lo que nos hace felices, entonces la obra de Traherne adquiere una nueva resonancia. Libros tales como los que él escribió se vuelven indispensables para la felicidad del propio autor porque son la expresión continua requerida para la perpetuación de la felicidad. Son también los maestros constantes que han desterrado el olvido del aprendiz que los escribe, buscando establecer una memoria siempre vigilante y siempre luminosa. La felicidad es la vista perfecta, la eterna lectura y, de manera inevitable, un eterno enseñar y una escritura sin fin. 


\section{Obras citadas}

ANON, 1675. The Art of Contentment. Oxford: s. e.

AsHMOLE, Elias, ed. 1658. The Way to Bliss (by John Grismond for Nath. Brook).

BARRow, Isaac. 1685. Of Contentment, Patience, and Resignation to the Will of God. Several Sermons. Londres: Flesher and Aylmer.

. 1680. Of the Love of God and our Neighbour. Londres: Flesher and Aylmer.

Bolton, Robert. 1638. A Discourse about the state of true hapinesse: deliuered in certaine sermons... Londres: Edmund Weauer.

BROOKS, George. 1654. Heaven on Earth. Londres: R.I. for John Hancock. BrooKs, Thomas. 1675. A Golden Key to Open Hidden Treasures. Londres: Dorman Newman.

1662. The Crown and Glory of Christianity. Or, Holiness the only way to happiness. Londres: H. Crips, J. Sims and H. Mortlock.

Browne, Thomas. 1981. Pseudodoxia Epidemica. Ed. Robin RoBbins. Oxford: Clarendon.

CHARRON, Pierre. 1651. Of Wisdom three bookes written in French. Londres: Luke Fawne.

CockBURN, John. 1686. Jacob's Vow, Or Man's Felicity and Duty. Edinburgo: J. Reid for Alexander Ogston.

CULVERWEL, Nathanael. 1652. An elegant and learned discourse of the light of nature. Londres: T. T. and E. M. for John Rothwell.

Fox, George. 1675. Possession above Profession. Londres: s. e.

GALE, Theophilus. 1676. "Wherein the love of the world is inconsistent with the Love of God", Sermon 3, A Supplement to the MorningExercise at Cripplegate... Londres: Thomas Cockerill.

. 1670. The Court of the Gentiles, Part II. Oxford: by Will. Hall for Tho. Gilbert.

GrossE, Alexander. 1640. The Happiness of Enjoying and Making a true and speedie Use of Christ. Londres: s. e.

HICKES, George. 1685. A Gentleman Instructed in the Conduct of a Virtuous and Happy Life. Londres: Kettilby.

HoBBES, Thomas. 1651. Leviathan, Or the Matter, Forme and Power of a Common-wealth, Ecclesiasticall and Civill. Londres: Andrew Crooke. HORNECK, Anthony. 1681. The Happy Ascetick. Londres: Jones and Loundes.

INGE, Denise, y MacFarlane, Calum. 2000. "Seeds of Eternity: A New Traherne Manuscript”. TLS, junio 2, 2000, núm. 5070, 14. Londres. 
JACKSON, Thomas. 1625. The Original of Unbeliefe, Misbelief and Mispersuation. Londres: Clarke.

London, William. 1965. A Catalogue of the Most Vendible Books in England $(1657,1658,1660)$. Ed. D. F. FoxON. Londres: British Museum.

LUCAS, Richard. 1685. Enquiry after Happiness. Londres: George Pawlett and S. Smith.

. 1696. Religious Perfection. Londres: Sam. Smith and Benj.

Walford.

MORE, Henry. 1690. An Account of Virtue. Trad. Edward Southwell. Londres: Benjamin Tooke.

OsBorn, James M. 1964. "A New Traherne Manuscript". TLS, octubre 8, 1964. 43-47. Londres.

. 1974. "The Osborn Collection, 1934-1974". Yale University

Library Gazette, octubre 1974, núm. 2, vol. 49, 1974-1975. 160-162.

PrITCHARD, Allan. 1983. "Traherne's Commentaries of Heaven (With

Selections from the Manuscript)". University of Toronto Quarterly, vol. 53, núm. 1, Fall, 1983. 1-35.

RosE, Elliot. 1982. "A New Traherne Manuscript". TLS, marzo 19, (4120). 324.

Rous, Francis. 1657. The Art of Happiness. Londres: Robert White.

SIBBES, Richard. 1862-1864. The Soul's Conflict with Itself en The Comple-

te Works of Richard Sibbes, DD. Ed. Alexander GROSART. Edinburgo: s. e.

SMITH, Julia. 1998. "The Ceremonial Law: A New Work by Thomas

Traherne (1637?-1674) With Extracts from the Manuscript". PN Review

124, noviembre-diciembre, vol. 25, núm. 2. 22-28.

TRAHERnE, Thomas. 1968. Christian Ethicks 1675. Ed. Carol L. MARKS y George GuFFEY. Ithaca: Universidad Cornell.

. Commentaries of Heaven, BL Add. MS 63054 (s. f.).

. 1997. Select Meditations. Ed. Julia SMITH. Manchester: Carcanet.

. 1906. The Poetical Works of Thomas Traherne, 1636?-1674.

From the Original Manuscripts. Ed. Bertram B. DoBELL. Londres: Dobell.

1958. Thomas Traherne: Centuries, Poems, and Thanksgivings. Oxford: Clarendon. 2 vols.

. 1910. Traherne's Poems of Felicity. Ed. H. I. BELL. Oxford: Clarendon.

Vaughan, Thomas. 1652. Aula Lucis, Or The House of Light. Londres: William Leake. [Signed S. N.]

VENNING, Ralph. 1655. The way to true happiness, or the way to heaven. Londres: T. R. and EM. For John Rothwell. 